\title{
Strontium ranelate reduced the risk of vertebral fractures in postmenopausal women with osteoporosis
}

Meunier PJ, Roux C, Seeman E, et al. The effects of strontium ranelate on the risk of vertebral fracture in women with postmenopausal osteoporosis. N Engl J Med 2004;350:459-68.

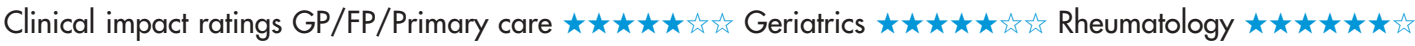

In postmenopausal women with osteoporosis, is strontium ranelate more effective than placebo for reducing the risk of vertebral fractures?

\section{METHODS}

-

Design: randomised controlled trial.

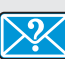

Allocation: unclear.*

Blinding: blinded (patients and healthcare providers).*

Follow up period: 3 years.

Setting: 72 centres in 11 European countries and Australia.

Patients: 1649 women who were $\geqslant 50$ years of age (mean age $69 \mathrm{y}$ ) and had been postmenopausal for $\geqslant 5$ years, had $\geqslant 1$

fracture confirmed by spinal radiography, and had a lumbar spine bone mineral density (BMD) $\leqslant 0.840 \mathrm{~g} / \mathrm{cm}^{2}$. Exclusion criteria were severe diseases or conditions that could interfere with bone metabolism or use of antiosteoporotic treatments (fluoride salts and bisphosphonates, oestrogen, calcitonin, or calcitriol).

$\mathbf{R}_{\mathbf{C}}$

Intervention: all patients received daily calcium supplements ( $\leqslant 1000 \mathrm{mg}$, depending on dietary intake) at lunchtime to maintain a daily intake $>1500 \mathrm{mg}$, and vitamin D (400-800 IU, depending on baseline serum concentration of 25 hydroxyvitamin D). After a run in period of 2-24 weeks, patients were allocated to strontium ranelate, $2 \mathrm{~g} /$ day (powder mixed with water) $(n=828)$ or placebo powder $(n=821)$ for 3 years.

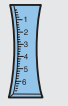

Outcomes: new vertebral fractures (a vertebral score change from grade 0 at baseline to $\geqslant 1$, where grade $0=$ normal; grade $1=20-25 \%$ decrease in vertebral height $[\mathrm{VH}]$; grade $2=25$ $40 \%$ decrease in $\mathrm{VH}$; grade $3=\geqslant 40 \%$ decrease in $\mathrm{VH}$ ), nonvertebral fractures, and bone mineral density (BMD) at the lumbar spine and proximal femur.

Patient follow up: $87 \%$ (intention to treat analysis).

*See glossary.

\section{MAIN RESULTS}

Fewer patients who received strontium ranelate had new vertebral fractures and vertebral height loss of $\geqslant 1 \mathrm{~cm}$ than patients who received placebo (table). Patients in the treatment group also had increased BMD at the lumbar spine, femoral neck, and total hip (mean percent change from baseline $14.4 \%, 8.3 \%$, and $9.8 \%$, respectively; $\mathrm{p}<0.001)$. The groups did not differ for non-vertebral fracture (table) or adverse events.

\section{CONCLUSION}

In postmenopausal women with osteoporosis, strontium ranelate reduced the risk of vertebral fractures.

For correspondence: Dr P J Meunier, Edouard Herriot Hospital, Lyons, France. pierre.meunier@laennec.univ-lyon 1.fr

Source of funding: Servier.
Strontium ranelate $v$ placebo for postmenopausal women with osteoporosis*

\begin{tabular}{lllll}
\hline $\begin{array}{l}\text { Outcomes at } \\
3 \text { years }\end{array}$ & Strontium & Placebo & RRR (95\% CI) & NNT (CI) \\
\hline $\begin{array}{l}\text { New vertebral } \\
\text { fracture }\end{array}$ & $21 \%$ & $33 \%$ & $36 \%(24$ to 47$)$ & $9(7$ to 14$)$ \\
$\begin{array}{l}\text { Vertebral height } \\
\text { loss } \geqslant 1 \mathrm{~cm}\end{array}$ & $30 \%$ & $37.5 \%$ & $20 \%(7$ to 31$)$ & $14(9$ to 40$)$ \\
$\begin{array}{l}\text { Non-vertebral } \\
\text { fracture }\end{array}$ & $16 \%$ & $17 \%$ & $8 \%(-17$ to 27$) \begin{array}{l}\text { Not } \\
\text { significant }\end{array}$ \\
\hline
\end{tabular}

*Abbreviations defined in glossary; RRR, NNT, and Cl calculated from data in article.

\section{Commentory}

Atrontium was originally identified in lead mines near Strontian, Scotland in the late 1700s. It was used to treat osteoporosis in the 1950 s but was found to cause unacceptable mineralisation defects due to the high doses used at the time.

A renewed interest now exists in strontium ranelate, which increases bone formation and decreases bone resorption. 4 major trials have examined strontium ranelate for the treatment of postmenopausal osteoporosis. 2 dose finding trials, PREVOS ${ }^{1}$ and SOTI ${ }^{2}$ (with a total sample of $>500$ women), showed that strontium ranelate increased corrected lumbar spine BMD in a dose dependent manner over 2 years (BMD must be corrected because strontium causes a false elevation in $\mathrm{BMD}$ as measured by DEXA).

The current 3 year trial by Meunier et al showed that $2 \mathrm{~g}$ daily of oral strontium ranelate reduced morphometric vertebral fractures by $47 \%$ (number needed to treat [NNT] = 17) at 1 year and by $36 \%($ NNT $=9$ ) by 3 years. These results indicate efficacy that is comparable to but not remarkably better than currently available osteoporosis agents. A large ongoing trial is examining the efficacy of strontium ranelate in preventing hip fractures in postmenopausal women with osteoporosis, and preliminary results are promising. ${ }^{3}$

Potential side effects of strontium ranelate include diarrhoea and asymptomatic transient increase in creatine kinase. However, before strontium can become an attractive treatment option for osteoporosis, studies of its long term safety, effectiveness, and cost effectiveness relative to other agents are needed.

Angela Cheung, MD Toronto General Hospital Toronto, Ontario, Canada

1 Reginster JY, Deroisy R, Dougados M, et al. Prevention of early postmenopausal bone loss by strontium ranelate: the randomized, twoyear, double-masked, dose-ranging, placebo-controlled PREVOS trial. Osteoporos Int 2002;13:925-31.

2 Meunier PJ, Slosman DO, Delmas PD, et al. Strontium ranelate: dosedependent effects in established postmenopausal vertebral osteoporosis-a 2 -year randomized placebo controlled trial. J Clin Endocrinol Metab 2002;87:2060-6.

3 Reginster JY, Sawicki A, Devogelaer JP, et al. Strontium randelate reduces the risk of hip fractures in women with postmenopausal osteoporosis. Osteoporos Int 2002;13:S14. 